Siris 3

(1832-1850)

\title{
Preparation of arseniuretted hydrogen
}

\section{Vogel}

To cite this article: Vogel (1838) Preparation of arseniuretted hydrogen, Philosophical Magazine Series 3, 13:83, 395-395, DOI: $10.1080 / 14786443808649605$

To link to this article: http://dx.doi.org/10.1080/14786443808649605

册 Published online: 01 Jun 2009.

Submit your article to this journal 준

LII Article views: 2

Q View related articles $₫$ 
PREPARATION OF ARSENIURETTED HYDROGEN. BY VOGEL.

When two equivalents of zinc are melted and one equivalent of powdered metallic arsenic added, they combine after stirring the mixture, which without any fresh application of heat becomes suddenly red hot. A little arsenic volatilizes, which burns on the surface of the mass with a blue flame. If we take equal equivalents of the two metals, the same evolution of heat occurs, but not to so great an extent, and the mixture cools more quickly. Antimony fused with zinc does not produce this phænomenon. This alloy of arsenic and zinc when pulverized and treated with hydrochloric acid, evolves arseniuretted hydrogen free from any traces of precombined hydrogen gas, as it is completely absorbable by a solution of sulphate of copper; and therefore affords the readiest and most convenient mode of procuring this gas free from admixture.-Journ. fuir Pract. Chemie, 6. 343.

[The Editors are obliged to Dr. Golding Bird for the preceding notices from the German.]

TUNGSTATE OF TUNGSTEN AND POTASH.

M. Laurent prepared this salt by the method employed by $M$. Wchler for the corresponding salt of soda. This tungstate crystallizes in small needles, whilst the soda salt is in small cubes.

M. Laurent states that the colour of this salt is extremely beautiful; it is of a deep coppery violet colour, and very brilliant when looked at in the sunshine; it very perfectly resembles sublimed indigo; and, what is remarkable, when burnished it becomes, like indigo, of a fine blue with coppery reflections. The corresponding salt of soda, whatever may be its colour, becomes blue by friction.-An. de. Ch. et de Ph. lxvii. 219.

\section{ANALYSIS OF SERUM OF BLOOD DRAWN FROM A DIABETIC PATIENT. BY DR. G. O. REES.}

Water ..................... 908.50

Albumen (yielding oxide of iron and phosphate of

lime by incineration)............. 80.35

Fatty matters .................. 0.95

Diabetic sugar ................. $1 \cdot 80$

Animal extractive soluble in alcohol, and urea .. $2 \cdot 20$

Albuminate of soda ................ 0.80

Alkaline chloride with trace of phosphate ....

Alkaline carbonate, trace of sulphate, the results $\} \quad 4 \cdot 40$

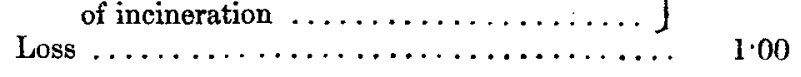

$1000 \cdot 00$

Guy's Hospital Reports, Oct. 1838.

AN ALYSIS OF THE LIQUOR AMNII.

Four specimens of this secretion recently examined by Dr. G. O. Rees, and described in the Guy's Hospital Reports, have yielded 